\title{
Cellular Tumor Antigen p53 Staining Method
}

National Cancer Institute

\section{Source}

National Cancer Institute. Cellular Tumor Antigen p53 Staining Method. NCI Thesaurus.

Code C122868.

An immunohistochemical technique used to detect the presence of cellular tumor antigen p53 in a tissue sample. 